Open Access

\title{
Reforms to China's financial administration following the 16th CPC National Congress
}

Kang Jia Correspondence: mofjk@163.com
Institute of Fiscal Science, Ministry
of Finance, Beijing 100142, China

\begin{abstract}
In November 2002, the 16th National Congress of the Communist Party of China proposed a blueprint of building a comprehensive well-off society in an all-round way in 2020. Since 2003, China's economic strength has been significantly enhanced. The socialist market economic system and its accompanying macro-control system have been improved. In response to some deep-seated contradictions and outstanding problems facing the economic and social development, the central government has proposed a series of solutions. This period is also the stage of improving and deepening China's financial reform. Great progress has been made in the reform of the basic framework of the fiscal system, the fiscal expenditure management reform, the tax reform, the financial management reform, and the financial macro-control. Moreover, new breakthrough and improvement initiatives are brewing.
\end{abstract}

Keywords: Fiscal reform; Macroeconomic regulation and control; Fiscal system reform

During the 16th National Congress of the Communist Party of China (CPC) in November 2002, plans were proposed to realize a relatively high living standard (xiaokang) across China by 2020. The accomplishment of this goal will mark an important stage in China's road to socialist modernization (becoming more prosperous, more democratic, stronger, and more culturally developed). The time period from 2003 through now is an opportune time for reforming China's fiscal system and bringing about new initiatives for general improvement.

During this period, China has gained significantly in economic strength. There have been continuous improvements to the socialist market economic system and its accompanying macroeconomic regulation system. Meanwhile, in the face of serious, deep-rooted problems affecting economic and social development, the CPC Central Committee proposed the "five balances" (balancing urban and rural development, balancing development among regions, balancing economic and social development, balancing development of man and nature, and balancing domestic development and opening up to the outside world), building a new socialist countryside, building a society with a relatively high living standard (xiaokang), building a harmonious society, and comprehensively implementing the Scientific Outlook on Development. Hu Jintao, General Secretary of the CPC Central Committee, said in the 17th CPC National Congress report that "we will improve the public finance system as we work to ensure equal access to basic public services and establish development priority zones. We

(c) $2015 \mathrm{Jia}$. Open Access This article is distributed under the terms of the Creative Commons Attribution 4.0 International License (http://creativecommons.org/licenses/by/4.0/), which permits unrestricted use, distribution, and reproduction in any medium, provided you give appropriate credit to the original author(s) and the source, provide a link to the Creative Commons license, and indicate if changes were made. 
need to deepen reforms to the budget system; tighten budgetary management and oversight; improve the system whereby both the central and local governments have financial resources proportionate to their duties and responsibilities; accelerate the establishment of a unified, standardized and transparent system for transfer payments; enlarge the size and proportion of general transfer payments; and increase inputs to public services. We will improve financial systems at and below the provincial level to enhance the capacity of county and township governments to provide public services. We will adopt fiscal and taxation systems conducive to scientific development and set up sound compensation systems for the use of resources and for damage to the environment."

Great progress has been made in reforming the basic framework of the fiscal system since the 16th CPC National Congress. First, innovations to the fiscal administration system below the provincial level have been promoted. To alleviate fiscal difficulties at the grassroots level and gradually solve excessive governmental budgetary levels and other problems, Hubei, Anhui, Jiangsu, Jiangxi, and other provinces have begun imposing direct provincial supervision onto county government finances on a trial basis. This has been done in Zhejiang province for many years already. Central Document No. 1 issued in 2006 proposed that governments in appropriate localities accelerate the process of placing county-level finances under direct provincial supervision. Due to differences between various counties, there are also large differences in the details of implementing direct provincial supervision over county finances. In some areas, the provincial government is to be placed in charge of a particular county's financial system, transfer payments, financial settlements, budget reporting, fund procurement, debt management, etc. In other areas, however, only subsidy allocations, fund procurement, and other major areas are to be placed directly under the management of provinciallevel governments. In 2011, the Ministry of Finance explained that in 2012, these pilot reforms would be carried out in all provincial-level administrative regions except ethnic minority autonomous regions. The implementation of this system has played an important incentivizing role in improving county governments' stability, management effectiveness, reduction of administrative costs, promotion of county economic development and private economy development, coordinated development of urban and rural areas, and the balanced development among administrative regions below the provincial level.

In addition, after the abolition of agricultural taxes and the implementation of reforms to the countryside tax system, Anhui Province began experimenting with county supervision of township finances. The rest of the county soon followed. Now, township budgets must be jointly compiled. That is to say, county-level finance departments set the emphasis of and propose the guidance for township budget plans. Under the guidance of county finance departments, township governments compile budget drafts and submit them for approval. Under the county management of township budgets, preexisting township bank accounts and all accounts in various financial institutions should be closed. County finance departments act as agents and open unified accounts and settlement accounts at various financial institutions within townships. Under the new system, budgetary revenues and extra-budgetary revenues of townships are placed under the management of county-level governments. Township fiscal expenditures should all be based upon the mutually established township budget. Priority should be 
given to ensure the payment of staff wages, and the unified system for wage payment should be gradually implemented. In addition, under the new system, the following should be implemented: unified procurements, unified bill management, networking counties with townships, and other management methods. County governments should institute the principles of ensuring wages, ensuring operations, protecting key projects, and maintaining stability in order to ensure the spending priorities of township finances and give priority to ensuring regular wage payment, ensuring normal government operations, and investing further in agriculture, education, health, social security, and other priority areas.

The logic of having government finances supervised from the level above is to reduce expenditure levels below the provincial level by introducing flattening reforms and gradually creating the conditions for the establishment of a new local tax system. Under this system, tax revenues would be shared by governments below the provincial level, and governments would implement trial reforms for collection of property taxes on personal homes and resources. Furthermore, these two reforms can help reduce administrative expenditures, as proposed by the Fifth Plenary Session of the 16th CPC Central Committee and the 17th CPC National Congress.

Second, systems to relieve county-township financial shortcomings and to improve transfer payments have been improved. Beginning in 2005, the transfer payment system of "Three Rewards and One Subsidy" to reward and subsidize county-township treasuries has been implemented to relieve county-township financial shortcomings. Rewards are given to county and township governments for increasing tax revenues and to provincial and municipal governments for increasing transfer payments to counties with fiscal difficulties. This is done in order to boost local governments' morale and to motivate county governments to relieve county-township financial shortcomings. Rewards should also be given to county and township governments for streamlining organizational structures and reducing staff in order to promote efficient administration and low government costs. Top grain-producing counties should also be subsidized in order to ensure food security and to increase incentives for grain production. Subsidies have been given to those regions which have done well relieving local financial shortcomings, in order to promote the principle of fairness. In recent years, the Ministry of Finance has made it a top priority to implement a county-level financial safeguard system.

Since the 16th CPC National Congress, great efforts have been made to adjust and improve the public expenditure system, enhance the supply of social services, and make the public finances more transparent. As government functions have changed and the market has taken a greater role in resource allocation, the functions and scope of government finance departments have also changed. Financial departments adhere to the principles of putting people first, thoroughly applying the Scientific Outlook on Development, focusing on establishing a long-term mechanism to safeguard and improve the people's livelihoods, continuously strengthening the effectiveness of public expenditures, and ensuring the quality of public services by optimizing the structure of public expenditures. Efforts have been made to ensure that rural citizens see more benefit from public expenditures; to support agriculture, rural areas, and farmers; to actively support the development of education; to make free compulsory education available to all rural and urban students by the fall of 2008; to grant financial assistance to students 
from poor families at normal undergraduate institutions, vocational colleges, and secondary vocational schools (to alleviate the ongoing issues of excessive costs of education and lack of access to schooling); to support the development of medical services; to promote and accelerate the establishment of a new cooperative medical care system in rural areas (in order to solve the outstanding issues of excessive cost and limited access to medical services); to invest further in the construction of the social security system; to establish and improve a variety of social security systems; to implement a baseline social security system for rural residents once the baseline guarantee system for urban residents is established to meet all life needs; to push forward the subsistence allowance system to rural areas and bring low-income housing under the umbrella of social security; to support ecological construction and environmental protection and promote the construction of a resource-saving and environment-friendly society; to support autonomous innovation and implementation of the National Medium- and Long-term Program for Science and Technology Development and key state science and technology projects; and to promote the construction of an innovative country. Since 2010, the Ministry of Finance has vigorously supported medical system reforms through increased investments. By medical system reforms, I refer to the building of a medical care system that covers all members of society within a few years. Preliminary data demonstrate that more than one trillion yuan has been invested in these reforms as of mid-2012. Since 2011, in order to cool down the real estate market and build a basic housing safeguard system, the government has allocated funds to raze shanty towns and build low-rent housing and public rental housing (collectively called "low-income housing construction"). In 2012, the current government will fulfill its commitment to make the annual government educational expenditures equivalent to $4 \%$ of annual GDP. Several financial initiatives have promoted the transformation of China's mode of development and the construction of a harmonious society.

Since the 16th CPC National Congress, as Reform and Opening up has deepened and both the economy and society have changed, in accordance with "implementing stepby-step reform to the tax system" as proposed by the Third Plenum of the 16th CPC Central Committee and the principle of "a more simplified taxation system, broader tax base, lower tax rates and stricter tax collection", the national government will take steps to "reform tax rebates on exporters; integrate enterprise taxes; transition the VAT taxbase from being production-oriented to being consumption-oriented and allow for tax rebates on equipment investments; improve the consumption tax and broaden its tax base appropriately; reform personal income tax (PIT) to implement a system that combines both comprehensive PIT and categorical PIT; carry out a tax-for-fee reform on urban construction to impose a unified property tax on real estate while abolishing current charges; empower local governments with taxation powers under unified tax codes; and create an environment for the integration of rural and urban tax systems." As compared to the tax reforms of 1994, the new tax reform will be launched in a structured, progressive fashion.

First, reforms to the tax and fee systems in rural areas have been comprehensively carried out in order to effect overall rural reforms. In 2004, subsidies were extended to grain farmers and special taxes on agricultural products, excluding tobacco, were abolished throughout China. In 2005, the livestock tax was completely rescinded nationwide, and the agricultural tax was rescinded in 592 key counties for national poverty 
alleviation and development work. The agricultural tax was completely rescinded nationwide in 2006, thus ending the thousand year history of grain taxes on Chinese farmers. This resulted in a fundamental change to the distribution relationship between the state and farmers. Since 2006, the nation has entered a new era in rural tax reforms, one characterized by institutional reforms to townships, reform to the compulsory education system in rural areas, reforms to the county and township financial management system, etc. In 2007, the national government mandated compulsory education in all rural areas and forced local governments to cover both tuition and miscellaneous education expenses under the social security system. Second, the government has steadily promoted VAT reforms. Pilot VAT reforms were launched in eight major industries throughout Northeast China in September 2004. This reform was then expanded to more than 20 industrial cities in central China in 2007. It was planned that all of China would be covered by the reforms in 2009. Third, there have been new steps taken in income tax reforms. Great progress has been made in the reform of corporate income taxes. The unification of tax codes on both domestically funded and foreign-funded enterprises in China on January 1, 2008 ushered in an era of equal enterprise taxation. The personal income tax threshold on wages and salaries was adjusted from 800 to 1600 yuan on January 1, 2006, further adjusted to 2000 yuan on March 1, 2008, and to 3500 yuan in 2011. There have also been adjustments to the progressive taxation scale, the classification range, and levels of taxation. Fourth, the government has rolled out financial and taxation policies conducive to saving resources and energy and developing new energy sources, and resource taxation policies have been improved. Beginning in Xinjiang in the second half of 2010, the government has implemented reforms to the calculation of resource taxes on crude oil and natural gas based on their prices instead of quantities. After a period of adjustments, this policy was extended nationwide in 2011, and will be extended to all resources in 2012. Fifth, pilot reforms to property tax on personal homes were launched in Shanghai and Chongqing in 2011. The scope of this pilot reform will be expanded once sufficient experience has been accrued. This reform is closely related to the establishment of local tax systems and the long-term healthy development of the real estate industry. It is an integral step in the optimization of distribution of income and property allocations. Sixth, business taxes have been replaced by the VAT, with Shanghai carrying out the pilot reform in January 2012. About ten provinces or cities across the country are expected to follow suit after August 2012. This reform was implemented for several reasons. One was to eliminate the double levying of business taxes. Another was to stimulate and guide those enterprises within the market affected by business tax and to eliminate the tendencies of taxes being "small but all-inclusive" or "large and all-inclusive", and to reduce the actual tax burden and form economic incentives for upgrading, thereby boosting consumption, expanding domestic demand and optimizing industrial structure. Seventh, in response to the global financial crisis, the central government implemented structural, macroeconomic tax reductions and selectively reduced the tax burden by half on small and medium enterprises in 2009. Also, the income tax threshold on small and micro businesses was raised from to 5000 Yuan to 20,000 Yuan in the second half of 2011. These measures have been instrumental for cyclical compensation, in improving the business environment and improving the people's livelihoods. Eighth, the central government passed a number of laws and regulations in the realm of tax collection and administration in 2004, 
such as the New Law of the Administration of Tax Collection. These measures were intended to strengthen taxation, improve normalization and promote continuous tax revenue growth.

Following the 16th CPC National Congress, in September 2007 the State Council issued the "Opinions of the State Council on the Trial Implementation of the Stateowned Capital Operations Budgets". The system highlighted in the document calls for, graded management, classified compilation and gradual implementation. This will be of great importance in strengthening the government's macro-control ability, deepening reforms to the state-owned assets management system, improving the income distribution system of state-owned enterprises and promoting the strategic adjustment of the pattern and structure of the state-owned economy. It will also be an important advancement in establishing a dual budget system under the public treasury umbrella. After 2008, a system has been enacted whereby large state-owned enterprises deliver a certain proportion of their annual return on assets to the state treasury. This system will be optimized in the future. In 2007, the Fifth Session of the Tenth National People's Congress adopted a new corporate tax law. The new law has gone into effect across the country since January 1, 2008. The standard income tax rate for domestically funded and foreign-funded enterprises in China has been unified at $25 \%$. Pre-tax deduction standards and tax preferences have also been unified. Over the past 30 years of Reform and Opening Up, China's corporate income tax has been unified for the first time. This ended the era of separate taxation standards for domestic and foreign enterprises. China's economy is further integrating with international standards, which is conducive to improving the tax environment for fair competition.

Since the 16th CPC National Congress, the supervision of public finances has been made more scientific and meticulous, and financial operations more standardized. First, placing township finances under the supervision of county governments has enabled refinements to workflow and ensuring basic grassroots units' management. Second, governments have continuously standardized budget management, established budget compilation workflow mechanisms, and constantly improved dynamic budgets. The central budget stabilization fund was established in 2006, subject to the oversight of the NPC, to make public finances more transparent and make the oversight of public finances more scientific. In 2007, reforms to state-owned capital operations budgets were implemented to promote the reform of state-owned enterprises and the development and standardization of the dual budget system. Reforms to the classification of government revenue and expenditures were also deepened in 2007, and government revenue classifications were unified. A new functional classification system for government expenditures and a new economic classification system for expenditures were established to reflect various concrete government revenue items and the contents and recipients of expenditures. This was done to change the situation in which outsiders cannot evaluate government finances, and to create favorable conditions to improve transparency and strengthen budget oversight. Third, financial supervision mechanisms have been gradually improved. In addition to maintaining the dual system of pre-auditing, continuous monitoring, and post-examination, governments have made efforts to increase supervision, strictly investigate and prosecute financial crimes and preliminarily establish financial supervision mechanisms to implement monitoring, comprehensive inspection, rectification and feedback, and tracking performance. Fourth, the 
construction of financial management information systems has been steadily advanced. The budget management system, the centralized treasury payment management information system and other e-business systems have been successfully developed and put into use. Databases for budget compilation, centralized payment, asset management and wage payment of administrative institutions have been established. Financial oversight has been improved continuously. Fifth, the performance appraisal of budget management has been actively promoted. Objective-based performance management, thirdparty assessment, full performance supervision, performance budget of key projects, and others have been developed to improve the comprehensive benefits of public funds. Sixth, efforts have been made to make government budgets and final accounts more open and budgetary work more transparent. First of all, more detailed departmental budgets and final accounts will be made available to the public. Information regarding government agencies' spending on official overseas trips, official vehicles, and official hospitality will be released to the public online, subject to the supervision of the entire populace. There will be more openness of budget information at and below the provincial level, as per central-level directives. Seventh, international exchanges and cooperation and strategic dialog and policy coordination have all been strengthened at the center. Efforts have been made to promote real regional cooperation and the economic integration of China with its neighboring countries through the ASEAN + 3 (China, Japan, and Korea) Meeting, the Greater Mekong Sub-regional (GMS) economic cooperation, and other mechanisms. This was done to strengthen China's international position in financial and monetary issues. This has been accomplished by actively using informal dialogs with Western finance ministers and central bank governors, the Group of Four Finance Ministers' Meeting, and other multilateral mechanisms and participating in the formulation and coordination of international economic rules through strengthening cooperation with the World Bank, the Asian Development Bank, and other international financial organizations.

Since the 16th CPC National Congress, the global economy has gradually recovered and the Chinese government began a policy of actively stimulating the economy. After successfully coping with the impact of the SARS epidemic in 2003, China's economy started to step out from the shadows of deflation and low levels of effective demand and entered a new period of prosperity. However, the problems of excessive investment and redundant construction began to pop up in some industries and regions. That was an indication that it would no longer be appropriate to continue to implement proactive fiscal policies that had been in place since 1998. The Central Committee looked into current economic conditions and began to study the idea of revamping fiscal policy in 2004. In 2005, the Committee began to implement prudent fiscal policy characterized by controlling deficits, adjusting structures, promoting reform, increasing revenues, and reducing expenditures. In the past few years, due to enhanced coordination of financial policies, monetary policies, and industrial policies, China's economy has experienced rapid growth, structural optimization, increased efficiency, and improved people's livelihoods. China's GDP maintained a growth rate higher than $10 \%$ without large fluctuations or severe inflation for five consecutive years between 2003 and 2007, resulting in gains to both the quality and efficiency of economic growth. Since the Reform and Opening Up, the Chinese government has adopted a variety of policy instruments to exert macro-control over economic operations and has gradually 
established a financial control mechanism characterized by coordinated budgets, taxes, subsidies on interest payments, government bonds, transfer payments, tax rebates on exporters, and other actions aimed to promote structural optimization and healthy, rapid economic development. In the fourth quarter of 2008, in the face of the global financial crisis triggered by the American subprime crisis, the CPC Central Committee and the State Council decided to change macro-policy. They again established a proactive, expansionary financial policy and pushed out a government stimulus package of four trillion yuan. These measures coupled with new monetary policies and other methods helped the national economy stabilize and recover after the second quarter of 2009. Moreover, the CPC Central Committee and the State Council make decisions discretionarily in complicated situations. They do so to strengthen and optimize preemptive adjustments and fine-tuning to policy, thus making progress while maintaining stability, all in order to promote the healthy, rapid development of the national economy. Since the 16th CPC National Congress, macro-control achieved through management of public finance has brought about four significant shifts: the shift from passive to active regulation, the shift from direct to indirect regulation, the shift from regulation by a single means to regulation by a combination of means, and the shift from regulating businesses and individuals toward regulating market variables. These shifts indicate that China has established a financial macro-control system that includes many elements, such as target selection, combined means, timing, organization, and implementation. This system basically meets the needs of different economic operation patterns under the market economy.

The main thrust of financial reforms since the 16th CPC National Congress has been to use public funds to safeguard and improve the people's livelihoods, to serve the overall national economy, and to push forward system construction. The Fourth Plenary Session of the Sixteenth Central Committee put forward the construction of a socialist harmonious society, and the 17th CPC National Congress proposed the strategic tasks and goals of applying the Scientific Outlook on Development. This implies a fundamental change in the social value orientation of the contemporary Chinese government. At a press conference with both Chinese and foreign reporters during the meeting of the 11th National People's Congress in early 2008, Premier Wen Jiabao said, "We will resolutely advance reforms to the public financial system to make it conducive to restructuring the economy and promoting the transformation of the mode of economic development, and improve the people's livelihoods and the ecological environment better... and so the people's money will be spent to better meet their needs." The core mission of public finance departments is to use taxpayers' money and financial and taxation policies to optimize and resolve the issues of allocation of public resources. These are issues that concern the majority of Chinese citizens, and public finances should be used for the benefit of all citizens. The government should give strong support to resolve basic livelihood issues with the financial resources available to them. This is the most basic requirement of the Scientific Outlook on Development: to promote social equality and to build a socialist harmonious society. In recent years, government spending on the people's livelihoods has become the priority of government budgets. Now and in the future, the main task for the financial system in China will be to increase investment in employment, social security, public health, compulsory education, low-income housing, and various social undertakings. Their goal should be to 
adjust income distribution across the levels of administration and bring about equal distribution of public services.

Ever since the new tax system went into practice, and since the proposal of the goals of "building a new socialist countryside," "building a harmonious society," and "thoroughly applying the Scientific Outlook on Development" were proposed in the 16th CPC National Congress, the basic ideas for deepening reforms to the financial system have been discussed and re-discussed. More stress has been laid on the reasonable division of duties among the various levels of government. The central government will introduce a taxation system in which revenue will be divided reasonably based on the duties of the various levels of government. It will also institute a scientific intergovernmental transfer payments system, making the governments' financial resources proportionate to their duties and responsibilities. There has been serious research conducted into the reform of the financial system below the provincial level, and some valuable suggestions have been put forward.

In the future, it should be stressed that the tax revenue sharing system, as the financial system for supporting China's market economy, should be implemented below the provincial level universally and consistently in the unified market by flattening reforms across all levels of government. Duties and financial privileges should be allocated corresponding to the level of a government, and duties should be proportionate to financial powers. Governments should be given authority to set tax levels and compile budgets according to their level. Furthermore, governments should be given property rights and debt financing powers corresponding to their level. According to the above principle, a long-term mechanism for tax revenue sharing should be established at the central level, the provincial level, and the municipal and county level. At the same time, the central government should implement reasonable, effective, top-to-bottom central-level and provincial-level transfer payments in order to make financial resources proportionate to duties and responsibilities, especially in the provision of basic public services in less developed areas. Steps should be taken to correct the biased and short-sighted funding of local governments through land transfers and to defuse risks of hidden debt in local governments. A strong financial and taxation system should be established to bring about a great national revival and the long-lasting stability of China.

Competing interests

The author declares that there is no competing interests.

Received: 23 September 2012 Accepted: 11 October 2012

Published online: 23 December 2015

\section{Submit your manuscript to a SpringerOpen ${ }^{\mathcal{O}}$} journal and benefit from:

- Convenient online submission

- Rigorous peer review

- Immediate publication on acceptance

- Open access: articles freely available online

- High visibility within the field

- Retaining the copyright to your article

Submit your next manuscript at $>$ springeropen.com 